\title{
Temporal variability in nitrification rates and related biogeochemical factors in Monterey Bay, California, USA
}

\author{
B. B. Ward* \\ Department of Geosciences, Guyot Hall, Princeton University, New Jersey, 08544 Princeton, USA
}

\begin{abstract}
The scales of temporal variability in the rate of ammonium oxidation and a suite of related biogeochemical parameters were investigated in the surface layer of the water column of Monterey Bay, California, on the west coast of the USA. Samples were collected on bimonthly (approx. every $2 \mathrm{mo}$ ) cruises during the course of 2 yr. The signal of El Niño was evident in the water column temperature and nitrate distributions during the initial cruise in February 1998. Throughout the 2 yr period, variation in temperature and salinity was small and consistent with seasonal upwelling. The biological parameters, however, varied much more than might have been predicted by the minimal variability in hydrographic signals. Ammonium assimilation rates, chlorophyll a concentrations and bacterial abundance varied by 41-, 65- and 147-fold, respectively. Ammonium oxidation rates often exhibited a subsurface maximum near the bottom of the euphotic zone, and varied by a factor of 4.5 over the $2 \mathrm{yr}$ study. The presence of the rate maximum was not obviously related to the dominant seasonal signals of hydrography or to other biological variables. Nitrification rates were much less variable in the bay than in Elkhorn Slough, a small estuary that opens onto the bay. The small variability in ammonium oxidation rates may be related to more dynamic responses in the community composition of the ammonia-oxidizing bacteria. Different groups of ammonia-oxidizing bacteria were detected as dominants in clone libraries from the Monterey Bay and Elkhorn Slough. The time scale of bimonthly sampling was evidently inadequate to resolve the response of nitrification rates to direct physical forcing in the bay.
\end{abstract}

KEY WORDS: Ammonium oxidation · Ammonium assimilation · Seasonal variability

\section{INTRODUCTION}

Nitrification is the microbially mediated process by which ammonium is oxidized to nitrate. This transformation of inorganic nitrogen in the euphotic zone of the ocean influences the availability of fixed $\mathrm{N}$ to primary producers, who differ in their ability to utilize nitrate versus ammonium. In this role, nitrification influences the distribution of nitrogen among various pools - an ecological role-rather than directly influencing the fixed $\mathrm{N}$ budget. The second major role of nitrification is more important in oxygen minimum zones and oxic/anoxic interfaces at sediments: nitrification produces the nitrate and nitrite that link organic $\mathrm{N}$ mineralization to denitrification and anammox, thus leading to loss of fixed $\mathrm{N}$ from the system.
Due to the widespread depletion of nitrate in surface ocean waters, it was previously assumed that nitrification rates in the euphotic zone were negligible. This implied that the only source of nitrate was mixing from subthermocline waters where, on the basis of the observed accumulation of nitrate, it was thought that nitrification proceeded more rapidly. This view changed with the direct measurement of nitrification rates showing that in the coastal and open ocean nitrification rates are maximal near the bottom of the euphotic zone. This distribution is considered to be influenced by light inhibition, which minimizes the activity of nitrifying bacteria in well-lit surface waters, and competition with phytoplankton for ammonium. Lowered light availability in the deeper regions of the photic zone limits the capability of phytoplankton to grow and 
assimilate $\mathrm{N}$, but has the opposite effect of liberating nitrifiers from light inhibition. This generally results in a distinct peak in nitrification, both ammonium and nitrite oxidation, in the depth range corresponding to $5-10 \%$ of surface light intensity (reviewed by Ward 2002). The subsurface nitrite maximum has been attributed to the differential light inhibition of ammonia- and nitrite-oxidizing bacteria (Olson 1981b). Thus the distribution of nitrate is the result of the net effect of nitrate production by nitrifying bacteria and the uptake of nitrate by autotrophic and heterotrophic microbes. The accumulation of nitrate in the deep water is due to the lack of a major sink for it, rather than the presence of a major production process.

The dependence of nitrification upon ammonium suggests that the rate of nitrification should vary depending upon ammonium concentration and supply. While pure cultures of nitrifying bacteria can be shown to demonstrate conventional uptake kinetics as a function of ammonium concentration (Carlucci \& Strickland 1968, Jones \& Morita 1983, Ward 1990), such dependence is usually not observed in natural assemblages (Olson 1981a, Ward 1987, Ward \& Kilpatrick 1990), with few exceptions (Hashimoto et al. 1983). It was concluded that ammonia-oxidizers in seawater must have very high affinities for ammonium, such that it is difficult experimentally to determine their response to substrate concentration at the relevant low concentrations (Hashimoto et al. 1983, Ward \& Kilpatrick 1990). Alternatively, the lack of response to ammonium concentration might be due to a dynamic response (e.g. change in community composition) of the ammonia oxidizing assemblage, which stabilizes the overall community response

If substrate concentration is always low, then its supply rate might be more important than absolute concentration in determining temporal variations in ammonium oxidation rate. In the high nutrient system of Monterey Bay, nitrate drives the major productivity trends, and ammonium supply, via remineralization and grazing, might be expected to correlate with primary production and chlorophyll a concentration. The primary goal of this study was to investigate temporal patterns in nitrification and related biological variables in Monterey Bay, where both episodic upwelling and underlying seasonal variation in light and mixing depth are important determinants of primary productivity. Additionally, we compare the observed rates and patterns in an upwelling region to (1) data from other oceanographic regimes, and (2) the same variables measured in the adjacent estuary, Elkhorn Slough. We hypothesized that greater temporal and spatial variability would be observed in the slough than in the bay, and that these in turn would be linked to differences in the composition and variability of the ammonia-oxidizing communities in the 2 environments.

\section{MATERIALS AND METHODS}

Experimental design. The study site was the central station (H3; Fig. 1) at approximately $900 \mathrm{~m}$ depth in Monterey Bay, California $\left(36^{\circ} 44.76^{\prime} \mathrm{N}, 122^{\circ} 01.30^{\prime} \mathrm{W}\right)$. This station is seaward of the main upwelling plume that is usually located north of, and within, the north end of the bay. H3 was sampled approximately bimonthly over a period of nearly $2 \mathrm{yr}$ on the following dates (19 February 1998, 2 April 1998, 1 July 1998, 19 August 1998, 29 October 1998, 21 December 1998, 16 February 1999, 16 April 1999, 14 July 1999, 20 August 1999, 19 October 1999). The depth of the euphotic zone was estimated with a Secchi disk and depths, corresponding to surface light intensities (93, $56,31,17,5.3,1$ and $0.1 \%$ plus 3 depths below the $0.1 \%$ light depth) for which incubators had been previously calibrated, were sampled using 101 Niskin bot-

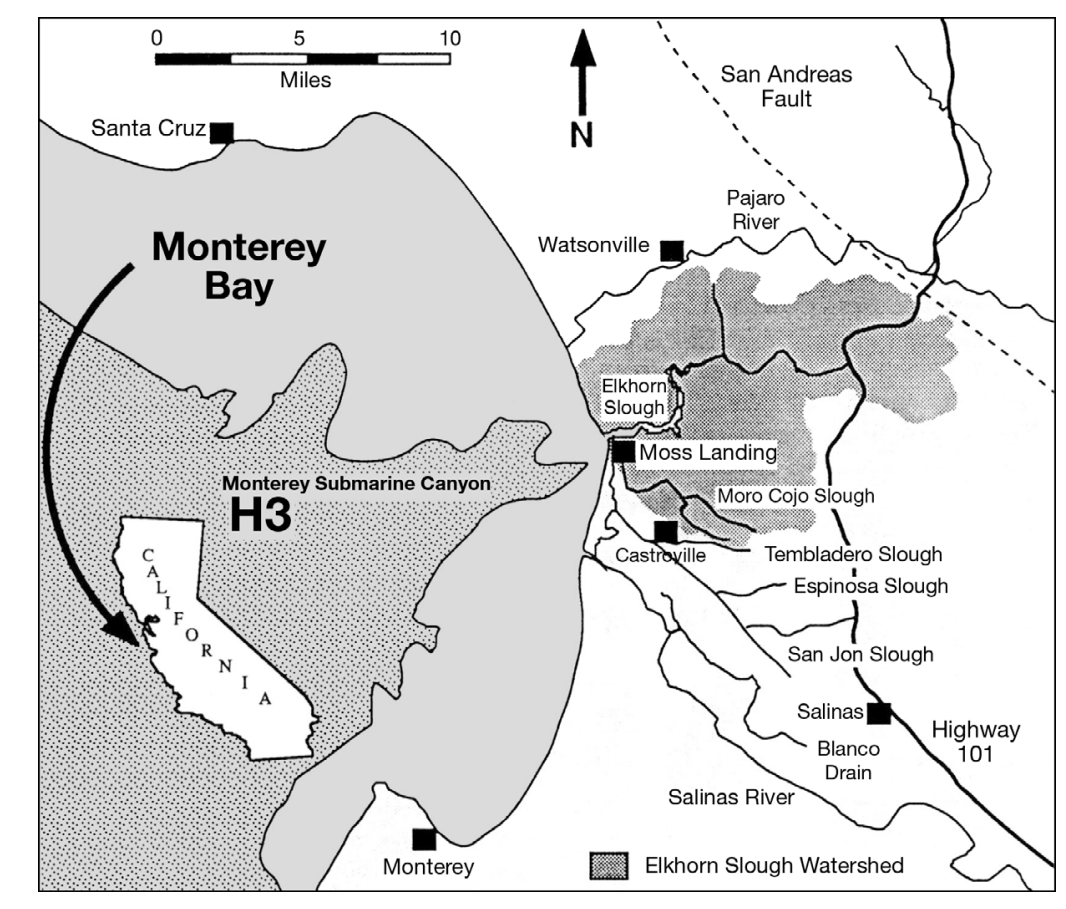

Fig. 1. Map showing proximity of Monterey Bay and Elkhorn Slough on the California coast. H3: study site 
tles mounted on a CTD rosette. Thus a total of 10 depths were sampled for measurements of nitrification rates, ammonium uptake rates, bacterial abundance, nutrient and chlorophyll distributions, and for collection of particulate material for later DNA extraction.

The DNA samples were intended for investigation of the distribution and diversity of ammonia-oxidizing bacteria (AOB) (in terms of 16S rRNA and ammonia monooxygenase genes) for comparison with the distribution of ammonium oxidation rates. Some of these results are presented elsewhere (O'Mullan \& Ward 2005). In addition, AOB diversity was investigated in the adjacent environment (Elkhorn Slough: Fig. 1). Those results have been published separately in conjunction with nutrient and nitrification rate measurements from that site by Caffrey et al. $(2002,2003)$, who described sequence-analysis methods and results and their findings are related to the current study in 'Discussion' below.

Rate measurements. Nitrification rates and ammonium uptake rates were measured in simulated in situ incubations on deck. Water was transferred from the Niskin samplers into $4 \mathrm{l}$ clear or opaque polycarbonate bottles, 2 bottles for each depth. Clear bottles were used for water collected from above the $0.1 \%$ light depth, and opaque bottles for deeper samples. ${ }^{15} \mathrm{~N}$ ammonium $\left(0.1 \mu \mathrm{M}\right.$ final concentration as $\left.\left(\mathrm{NH}_{4}\right)_{2} \mathrm{SO}_{4}\right)$ as tracer and ${ }^{14} \mathrm{~N}-\mathrm{NO}_{2}(0.2 \mu \mathrm{M}$ final concentration as $\mathrm{NaNO}_{2}$ ) as carrier were added to each bottle and mixed well. Bottles were then securely capped and enclosed in plastic screen bags to achieve the light intensity from which the samples originated. (The screen/ bottle/incubator combinations had been previously calibrated using a Biospherical light meter.) Bottles were then incubated in running seawater incubators on deck for 3 to $6 \mathrm{~h}$. The temperature of the incubators was monitored and it generally stayed within $2{ }^{\circ} \mathrm{C}$ of the coolest sample temperature. Samples were never collected from deeper than $100 \mathrm{~m}$ and the temperature structure of the bay ensured that surface water was never much warmer than the water at the deepest sample depth (see first subsection of 'Results').

Ammonium uptake and oxidation were measured from the particulate material on the filter and the nitrite in the filtrate, respectively, of each sample. After incubation, the entire contents of the bottles were filtered under gentle suction pressure through precombusted GF/F filters. The filters were frozen for particulate nitrogen $(\mathrm{PN})$ analysis (in order to determine ammonium uptake into the PN fraction), and the filtrates were also frozen (in order to determine ammonium oxidation into the nitrite fraction). Upon return to the laboratory or within 2 mo of storage in the freezer, dissolved nitrite was extracted from filtrates (Ward 1987) and the resulting azo-dye was dried down onto precombusted GF/F or GF/C filters. A Europa 20:20 isotope ratio-mass spectrometer was used to measure the ${ }^{15} \mathrm{~N}:{ }^{14} \mathrm{~N}$ ratio of the particulate material and the azo-dye on triplicate subsamples of each filter.

The simple equations of Dugdale \& Goering (1967) were used to compute uptake and nitrification rates; i.e. we did not account for regeneration of ammonium and the effect of variable isotope dilution on the substrate pool during the incubation. The minimal length of the incubations was intended to minimize the impact of dilution, but to the extent that the degree of dilution is unknown, the computed rates no doubt underestimate the in situ rates. Initial ambient $\mathrm{NH}_{4}{ }^{+}$ concentrations were low and not dramatically variable over the year or with depth (see first subsection of 'Results'); therefore we assumed that the addition of the tracer doubled the ambient pool and adjusted the substrate at. \% value in the rate calculations accordingly (i.e. assumed it was 49.5 at.\% for all samples). The assumption would result in an overestimation of the rate if ambient $\left[\mathrm{NH}_{4}{ }^{+}\right]$was significantly lower than $0.1 \mu \mathrm{M}$ and an underestimation if ambient $\left[\mathrm{NH}_{4}{ }^{+}\right]$ exceeded $0.1 \mu \mathrm{M}$.

Analytical methods. Bacterial abundance was estimated by direct epifluorescence enumeration using DAPI and a Zeiss Axioskop with 1200x magnification on samples that had been preserved in formalin at the time of collection. Prior to counting, samples were stored at $4^{\circ} \mathrm{C}$ for up to $4 \mathrm{wk}$. Dissolved inorganic nitrogen (DIN) concentrations were determined using a Lachat autoanalyzer or manually using standard colorimetric techniques (Strickland \& Parsons 1972, Grasshof et al. 1983). For analysis of particulate chlorophyll, 1 l samples were filtered onto GF/F filters and the filters were frozen. The frozen filters were extracted overnight in $90 \%$ acetone, centrifuged and read on a Turner Model 10 fluorometer (Turner Designs) (Parsons et al. 1984). Statistical analyses were performed with SPSS 11.0 (SPSS). Linear regression was used to compare 2 variables. Multiple regression and analysis of variance were used to investigate relationships among many variables (or among subsets of the variables when not all variables were measured on each date). In the following, significance or lack thereof refers to these analyses; significance was indicated by $\mathrm{p}<0.100$.

\section{RESULTS}

\section{Seasonal and annual variability in Monterey Bay}

Temperature (T) and salinity (S) are the usual hydrographic indicators of the fundamental basis of seasonality in marine environments. In Monterey Bay over 

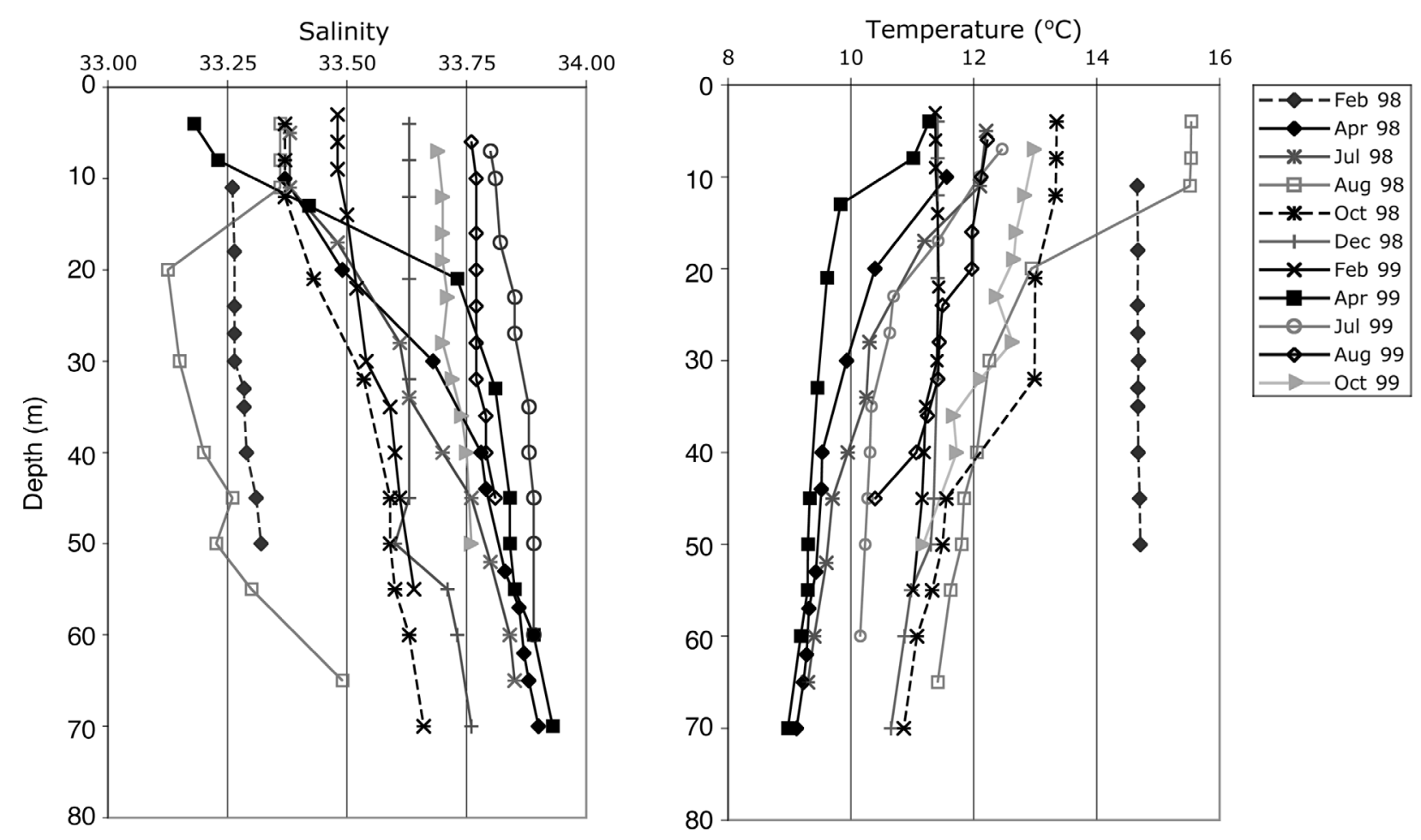

Fig. 2. Seasonal patterns in salinity and temperature in Monterey Bay in 1998 and 1999

the period from February 1998 to October 1999, salinity showed minimal temporal and vertical variability in the upper $70 \mathrm{~m}$ (Fig. 2). The total data set ranged over less than 1 ppt, from 33.1 in August 1998 to 33.9 in July 1999. The 2 dates with the lowest salinity throughout the surface layer were February and July 1998. Salinity was generally minimal in the surface, especially in 1998, and increased slightly with increasing depth. This degree of salinity variation is probably significant in the small scale stability of the surface layer (reflecting rain and episodic runoff events from the nearby California coast), but is not significant in terms of a direct physiological response of microorganisms to salinity.

The variation in temperature throughout the study period was also minimal, with a few interesting signatures (Fig. 2). The water column was completely well mixed in February 1998, with no variation in either S or $\mathrm{T}$ over the top $50 \mathrm{~m}$. The temperature on that date was, however, the warmest recorded during this study, with the single exception of the top $10 \mathrm{~m}$ in August of 1998. The February temperature of $14.7^{\circ} \mathrm{C}$ is the signature of El Niño, which struck the California coast with strong storms during that month. The highest winds and greatest rainfall occurred approximately 2 wk prior to the sampling date, but the signature of El Niño was clear in the bay for at least that long (including low surface salinity). By the next sampling date, 2 mo later, the deeper water had cooled to its normal winter/spring temperature of around 9 to $10^{\circ} \mathrm{C}$.

Another interesting feature of the temperature distribution is the seasonal warming of the surface layer, which may have extended to greater depths than we sampled. However, strong warming in the top 10 to $15 \mathrm{~m}$ was observed both in August 1998 and in April 1999, indicated by the 1 to $2^{\circ}$ gradient between 0 and 10 or $11 \mathrm{~m}$. The temperature of the water between 10 and $70 \mathrm{~m}$ varied by no more than $4^{\circ} \mathrm{C}$ over the annual cycle, with the exception of February 1998. The maximum variation within 1 profile was $3^{\circ} \mathrm{C}$. The coolest subsurface temperatures were recorded in April and July of both years and in August of 1999, which is consistent with the general upwelling seasons in the area (and with generally higher $\left[\mathrm{NO}_{3}{ }^{-}\right]$on those dates; see below). Those 5 dates also had the highest subsurface salinities (Fig. 2), indicative of upwelled water. The time scale of upwelling events is on the order of 4 to $10 \mathrm{~d}$ (Dugdale et al. 1990, Wetz \& Wheeler 2003), and the focus of upwelling in Monterey Bay is to the north of the station studied here. Therefore, the hydrographic signature of upwelling was detectable but not dramatic in the bimonthly records at Stn H3.

The depths of the $1 \%$ light intensity and the depth distributions of chlorophyll and nitrate are indicators of biological seasonality. The $1 \%$ light depth, as estimated by Secchi disc measurement at mid-morning, varied 


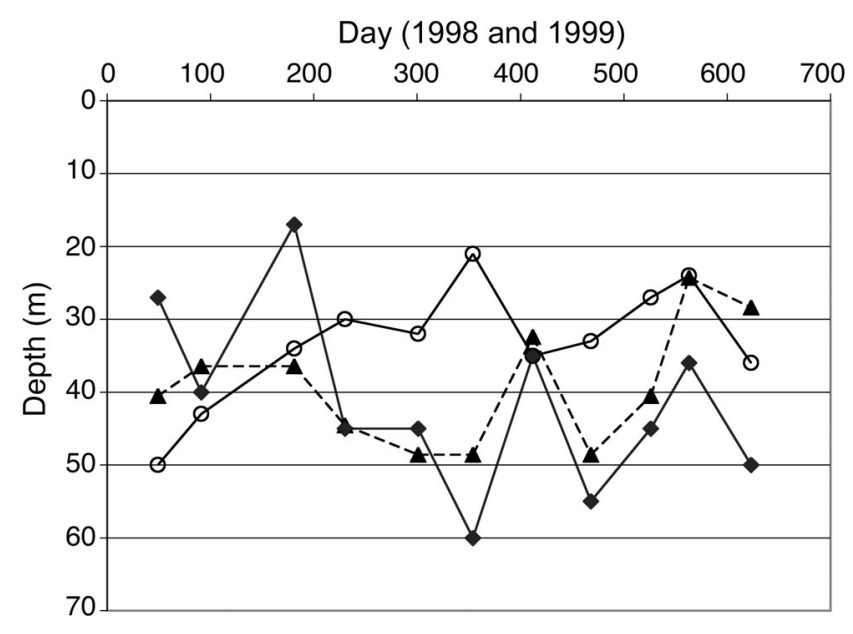

Fig. 3. Seasonal variation in depth of $1 \%$ surface light intensity $(\boldsymbol{\Lambda}),\left[\mathrm{NO}_{2}^{-}\right]$maximum (O) and ammonium oxidation rate maximum ( $\bullet$ ) in Monterey Bay during the study period (February 1998 to February 1999)

from 24 to $49 \mathrm{~m}$ (average $=37 \mathrm{~m} \pm 10.4 \mathrm{~m}$ ) and was not a simple function of time of year. The depth of the subsurface nitrite maximum $(29.3 \pm 6.2 \mathrm{~m})$ was not correlated with the $1 \%$ light depth (Fig. 3). Only in late summer of 1998 (August and October) did chlorophyll a exhibit a distinct subsurface maximum. At all other times, including October 1999 (data not available for August 1999) maximum chlorophyll a abundance was near the surface and the concentration gradually decreased with increasing depth (Fig. 4A). Chlorophyll a levels and distribution in February 1998, the El Niño year, were moderate (in the middle of the range observed for the whole study) and very similar to those observed in February 1999, the subsequent non-El Niño year.

Nitrate concentration (mean of 2 replicates) varied greatly with both date and depth. Lowest $\left[\mathrm{NO}_{3}{ }^{-}\right]$ throughout the water column occurred in February 1998 and February 1999 (Fig. 4B), and were particularly low during the El Niño year, 1998. Highest water column $\left[\mathrm{NO}_{3}{ }^{-}\right]$occurred in April and July of 1998 and in August of both years. On these 4 dates, $\left[\mathrm{NO}_{3}{ }^{-}\right]$at the shallowest sampling depth was never less than $15 \mu \mathrm{M}$. The high $\left[\mathrm{NO}_{3}{ }^{-}\right]$in April 1998 may reflect a dramatic change of water mass after the ebbing of El Niño. The late summer distributions are consistent with the typical upwelling season in this area. Ammonium concentration never exceeded $0.08 \mu \mathrm{M}$, and at this level it is not possible to detect significant depth variations on the basis of the standard colorimetric assay. Nitrite concentration usually exhibited a small maximum (whose depth is shown in Fig. 3), and the highest observed concentration was $0.53 \mu \mathrm{M}$ (July 1999).

Bacterial abundance varied by approximately 1 order of magnitude (excluding 3 anomalously low values, approximately $2 \times 10^{5}$ to $2 \times 10^{6}$ cells $\mathrm{ml}^{-1}$ ) over the entire data set, and generally decreased with increasing depth within sampling dates (Fig. 5). Highest abundance was observed in the surface samples in July 1999 and lowest abundance occurred in February 1999 between 30 and $40 \mathrm{~m}$. While abundance was often greatest in the surface samples, most profiles
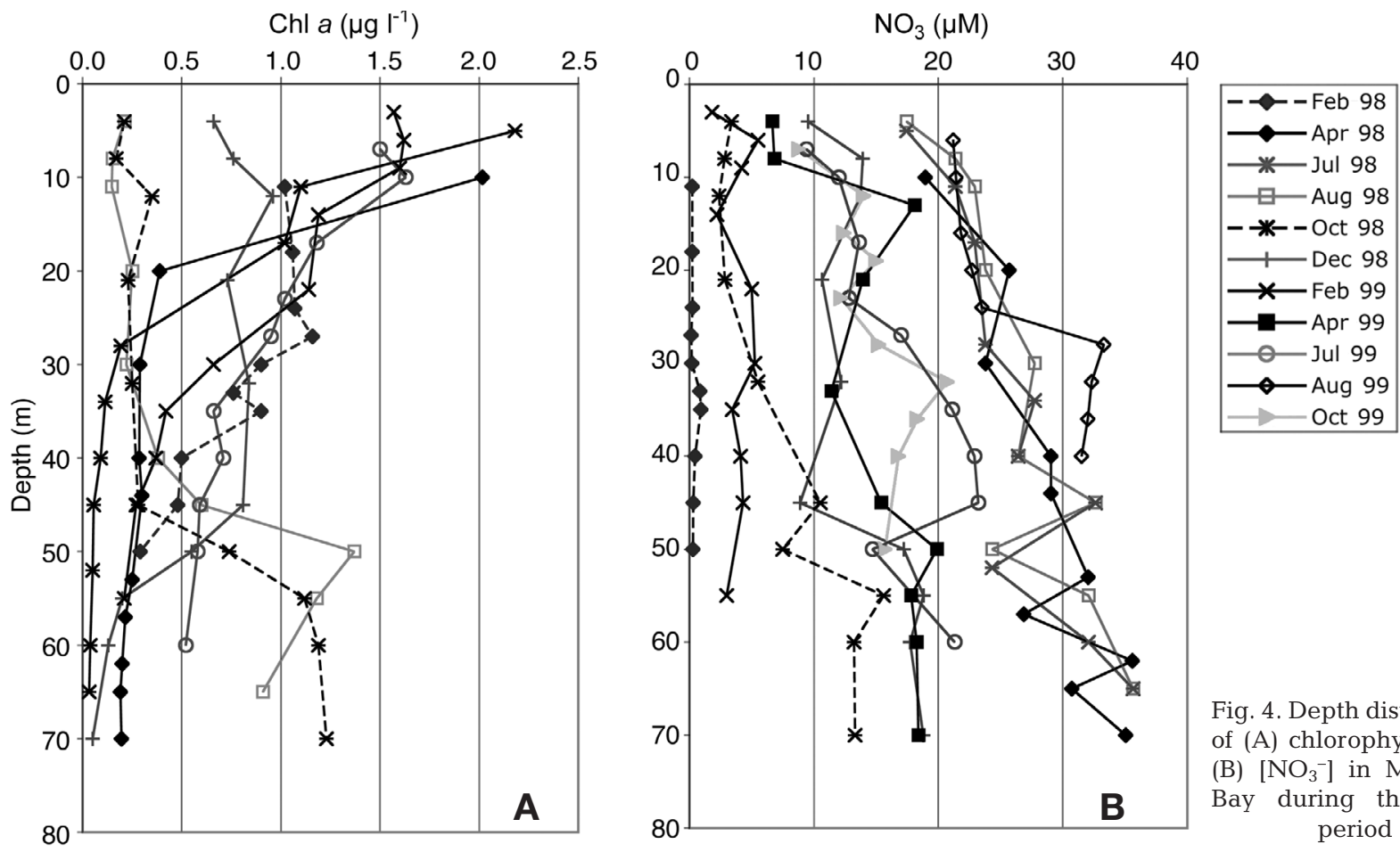

Fig. 4. Depth distribution of (A) chlorophyll $a$ and (B) $\left[\mathrm{NO}_{3}^{-}\right]$in Monterey Bay during the study 

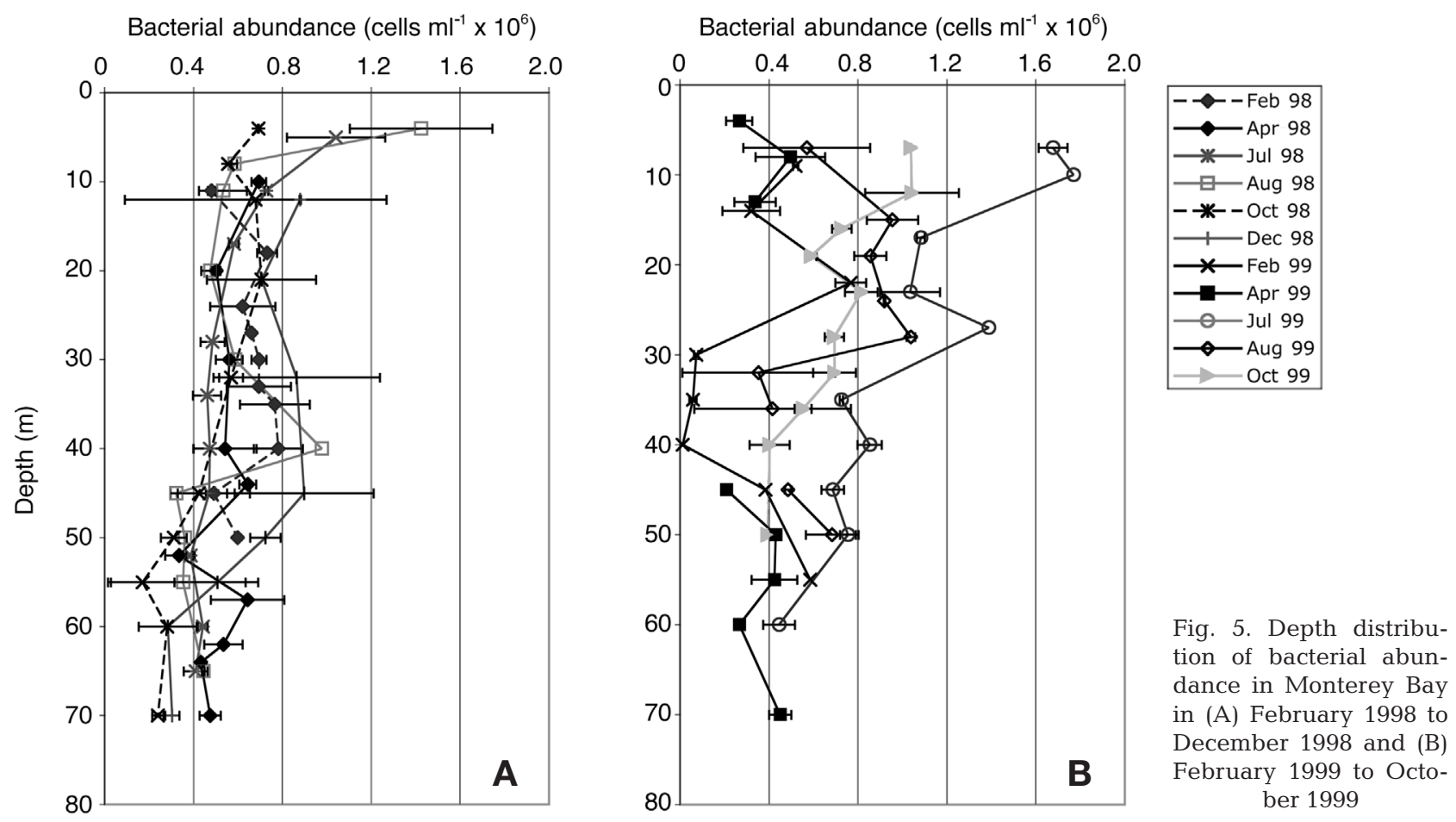

exhibited peaks at other depths as well. The counts were rather variable (standard deviations based on counts from up to 100 microscope fields enumerated for duplicate filters), but within the range generally reported for total counts in surface seawater. The low counts at 30 to $40 \mathrm{~m}$ in February 1999 seem anomalous, but are reported because the data were replicated and there is no obvious reason to disregard them.

\section{Ammonium oxidation and assimilation rates}

The depth distribution of nitrification (ammonium oxidation) rates was much more variable than that of temperature, but did not always show strong maximum and minimum features (Fig. 6). Rates ranged from $<20$ to nearly $80 \mathrm{nmol} \mathrm{N}{ }^{-1} \mathrm{~d}^{-1}$. The lowest rates were generally in the surface samples ( 4 to $11 \mathrm{~m}$ ) and the highest rates at greater depths, often in a discrete maximum. The rates plotted in Fig. 6 are the means of replicate incubations; the range of replicate values as a percentage of the mean of 2 values varied from zero to $79 \%$; when the 4 cases out of 110 (July 1998, 11 and $17 \mathrm{~m}_{\text {; }}$ August 1999, 32 and $36 \mathrm{~m}$ ) in which the variation was greater than $70 \%$ are omitted, the average range among replicates was $9.75 \%$ of the mean, and the median of ranges was $5.52 \%$.

With 3 exceptions, the depth of maximum nitrification rate was between the depths corresponding to 1 and $0.1 \%$ of surface light intensity (Figs. 3 \& 6). In Feb- ruary and July 1998 the depth of maximum nitrification was shallower than the $1 \%$ light depth, and in October 1999 the maximum rate was at $50 \mathrm{~m}, 4 \mathrm{~m}$ below the $0.1 \%$ light depth. The depth variation in nitrification rate was greatest in February 1998, when the maximum rate was 4 -fold greater than the minimum, and least in December 1998 and April 1999, when the difference was 1.6-fold. On 5 cruises, there was no strong peak in the rate distribution.

Integrated nitrification rates over the depth interval covered by rate measurements (approximately the surface to the $0.1 \%$ light depth) averaged $2.0( \pm 0.55) \mu \mathrm{mol}$ $\mathrm{m}^{-2} \mathrm{~d}^{-1}$ over the 11 profiles, and varied by a factor of 2.46 between the highest (October 1998) and lowest (July 1998) sampling dates. Rates were higher (average $\left.=2.27 \mu \mathrm{mol} \mathrm{m}^{-2} \mathrm{~d}^{-1}\right)$ and more variable $(\mathrm{SD}=0.63)$ in 1998 than in $1999\left(1.68 \pm 0.18 \mu \mathrm{mol} \mathrm{m}^{-2} \mathrm{~d}^{-1}\right)$.

Ammonium assimilation rate data are available only for the last half of the study, and exhibit conventional seasonal and depth variability (Fig. 7). Lowest rates were observed in December 1998 and October 1999. The assimilation rate generally decreased with increasing depth and displayed a distinct subsurface maximum only in August 1999 (the subsurface maximum in October 1999 was a single point). Integrated assimilation rates over the depth interval between the surface and the $0.1 \%$ light depth averaged 5.10 $( \pm 1.31) \mu \mathrm{mol} \mathrm{m} \mathrm{m}^{-2} \mathrm{~d}^{-1}$ and ranged from $2.83 \mu \mathrm{mol}$ (October 1999) to $6.67 \mu \mathrm{mol}$ (August 1999) $\mathrm{m}^{-2} \mathrm{~d}^{-1}$, varying by a factor of 2.34 . 


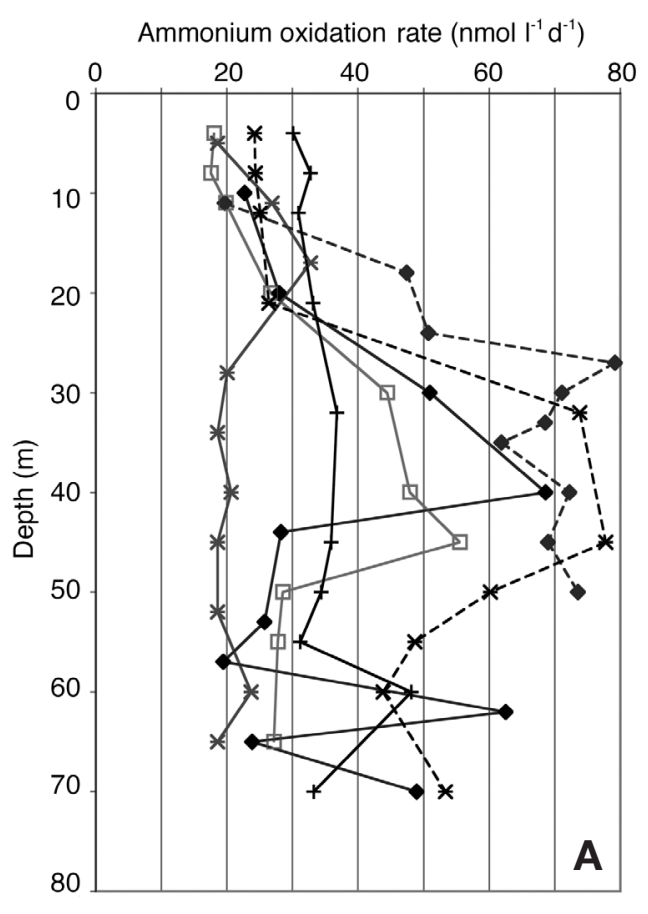

DISCUSSION

\section{Seasonal patterns and correlations}

Relatively little seasonal and annual variability was evident in the hydrographic variables, but biological rate and biogeochemical parameters were much more dynamic. The patterns reflect the expected relationships between depth and chlorophyll, nitrate, ammonium assimilation and bacterial abundance that characterize an upwelling system. The El Niño signal was strong in terms of temperature and nitrate distribution in February 1998. Although the bimonthly sampling scheme was not adequate to capture the temporal relationships among factors that vary on the upwelling time scale, it may be possible to discern other relationships when considering the 2 yr data set as a whole. Even lack of such relationships can be informative, suggesting the need for additional information or the importance of different time scales.

The magnitude of variation in ammonium oxidation rates over the entire data set was limited to a factor of approximately 4.5 -fold (17.5 to $79.2 \mathrm{nM} \mathrm{d}^{-1}$ ). This is a small dynamic range compared to the variation in ammonium assimilation rates, and in concentration variables such as chlorophyll, nitrate, and bacterial abundance, which varied by 41-, 65-, 240- and 147 fold, respectively. This low variability may be related to the dependence of nitrification on the supply of ammonium. Because $\left[\mathrm{NH}_{4}{ }^{+}\right]$is generally low and its variability insignificant at the sensitivity of our colori- metric analysis, we could not investigate a potential relationship between $\left[\mathrm{NH}_{4}{ }^{+}\right]$and uptake or nitrification rates. Instead, in order to investigate a potential relationship between remineralization rates (ammonium supply) and the uptake or oxidation of ammonium, we

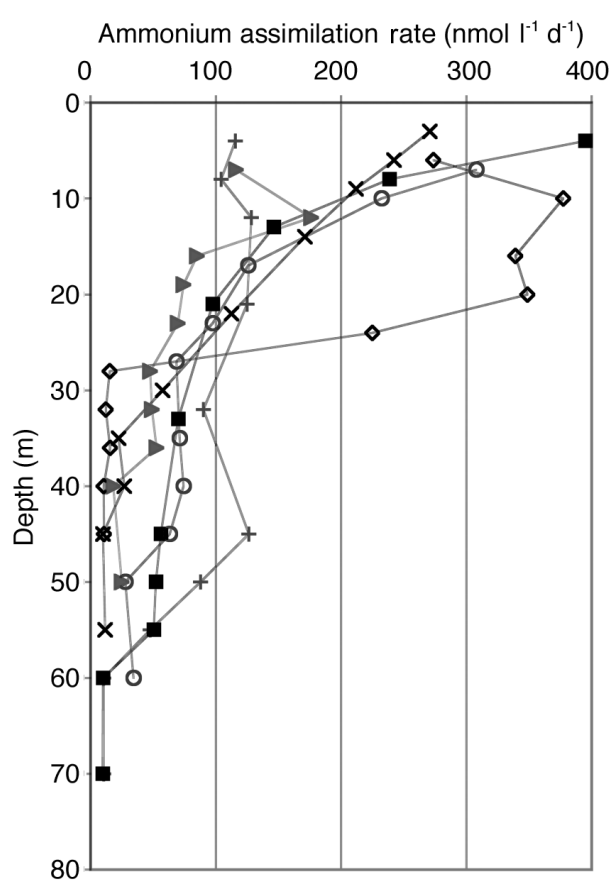

Fig. 7. Depth distribution of ammonium assimilation rates in Monterey Bay during the study period. Cruise symbols as in Fig. 2 

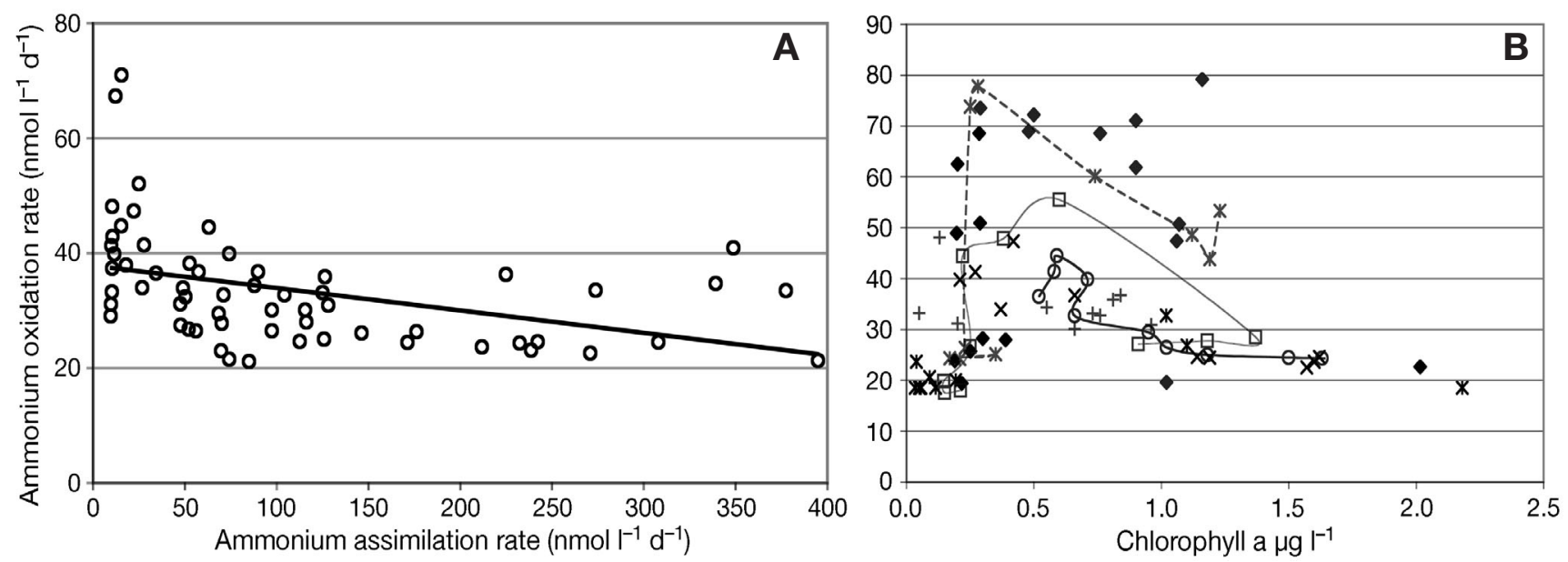

Fig. 8. Relationship between rates of ammonium oxidation and (A) assimilation in Monterey Bay for all dates on which both rates were measured (December 1998 to December 1999) and (B) chlorophyll a concentration for cruises on February 1998 to February 1999 and July 1999. Symbols as in Fig. 2

investigated several proxies. Chlorophyll a should represent a rough estimate of phytoplankton biomass, which results from uptake of DIN. However, the abundance of $\mathrm{NO}_{3}{ }^{-}$in this system and its role as a controlling variable (Kudela et al. 2000, Bruland et al. 2001) suggest that neither supply rate nor concentration of $\mathrm{NH}_{4}{ }^{+}$is likely to control or correlate with chlorophyll a levels or primary productivity rates. However, if ammonium supply derives mainly from remineralization, which depends on organic matter supply and grazing of phytoplankton biomass, then a correlation between ammonium supply and chlorophyll a concentration might result. $\mathrm{NH}_{4}{ }^{+}$uptake rate, although probably not a controlling factor in the growth of the dominant large phytoplankton, might be expected to correlate with ammonium oxidation rates, if both rates are dependent upon substrate concentration or supply. The 2 rate processes respond oppositely to light, however, and therefore a potential dependence on the substrate concentration may not be evident.

In fact, ammonium oxidation rates and ammonium assimilation rates were not significantly correlated (Fig. 8A); the highest rates of nitrification occurred at depths with lowest assimilation rates, due to the inverse relationship between the 2 variables and light intensity. Low nitrification rates also occurred at depths with low assimilation rates; again the tendency for nitrification to exhibit a subsurface maximum precludes simple linear relationships between nitrification and variables that vary directly with light intensity or temperature (and therefore depth). Only 6 of the 11 ammonium oxidation rate profiles exhibited distinct subsurface maxima (Fig. 6), and those dates were not characterized by any particular relationship to other variables; e.g. they were not divided among upwelling and non-upwelling or winter seasons. The rate distributions from July 1998, December 1998, April 1999 and October 1999 were fairly uniform over the depth interval measured or showed maxima that were not defined by more than one point (Fig. 6). There was no significant relationship between the depth of maximum ammonium oxidation rate and the depth of the $1 \%$ light level or the depth of the $\left[\mathrm{NO}_{2}^{-}\right]$maximum.

For the same reason, there was no simple relationship between nitrification rate and chlorophyll a concentration in the data set as a whole (Fig. 8B). In several individual profiles, nitrification rate was maximal at intermediate to low chlorophyll a concentrations. This was most striking in August and October of 1998, when nitrification rate had a distinct maximum and chlorophyll a concentration exhibited a strong subsurface maximum that was deeper than the maximum in nitrification rate. The same relationship, but less dramatic, was seen in February and July 1999, when chlorophyll concentration showed a general decrease in concentration with depth and nitrification rates had weak maxima at intermediate depths.

The relationship between nitrification rate and light intensity is important, but light is obviously not the only determinant of the rate. Highest rates always occurred at the lowest light intensities, but the lowest rates occurred at all light intensities (Fig. 9).

Multiple regression analyses including only independent variables which were measured at all depths on all dates (depth, day of the year, bacterial abundance, nitrate concentration, \% surface light intensity, temperature and salinity) detected significant correlations for nitrification only with \% surface light intensity $(p=0.009)$ and depth $(p=0.016)$. Both these correlations were evident from property-property plots and 


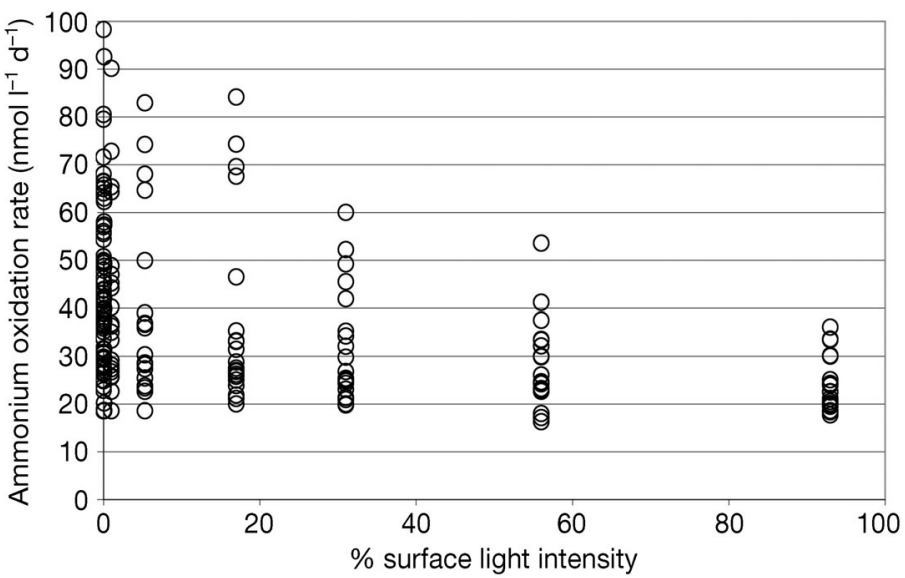

Fig. 9. Relationship between ammonium oxidation rate and light intensity in Monterey Bay. Oxidation rate $=-0.204$

$(\%$ surface light intensity $)+40.41\left(\mathrm{~N}=109 ; \mathrm{R}^{2}=0.386\right)$

are consistent with the observed depth variation in all 3 factors, despite the nonlinear pattern of nitrification rate with depth (see foregoing paragraph). Because of the missing data for several cruises, these are the only variables for which the entire 11 cruise data set could be analyzed. This overall regression was highly significant ( $p<0.0001)$, but explained less than $40 \%$ of the variability in nitrification rate $\left(\mathrm{R}^{2}=0.389\right)$, implying that other unidentified factors are involved-possibly the composition of the bacterial community.

When ammonium assimilation rate was also included in the analysis, the data set was reduced by half and included only the last 6 cruises. In this analysis, the correlation between ammonium oxidation rate and light intensity was no longer significant, which is consistent with the much reduced vertical variability in nitrification rates observed in 1999, compared with those in 1998 (Fig. 6).

The low degree of variation in the ammonium oxidation rate might result from artifacts associated with the measurement, including (1) perturbation of the substrate level by tracer addition, and (2) our failure to quantify ammonium regeneration in the incubation bottles. Of course, these potential artifacts would be of equal significance in the determination of ammonium assimilation rates. Those rates, however, varied by a factor of 41 -fold over the 6 dates for which assimilation rates were measured. Thus, although there may be inaccuracies in the rate measurements due to these artifacts, they are probably not responsible for the lack of variability in the ammonium oxidation rates. Short incubations were used to minimize the effect of isotope dilution on the rate calculations, but dilution no doubt occurred to a variable extent in the bottles and must have caused an underestimation and some undetected variability in both oxidation and assimilation rates. The reason for the greater variability in assimilation rates probably relates to the greater variability in chlorophyll (biomass) in space and time. Few data are available for the temporal and spatial variability in abundance of ammoniaoxidizing bacteria (AOB), but the existing reports suggest that AOB constitute a small and minimally variable fraction of the total bacterial community (Ward 2002).

Ammonium oxidation rates were not obviously related to indicators of either ammonium concentration or ammonium supply rate. In a well mixed surface layer (i.e. very little variation in $\mathrm{S}$ and $\mathrm{T}$ over the study period) it may be that nitrifiers are unable to respond to small scale variability in the ammonium pool. The rates reported here are on the high side for open ocean or coastal water column environments (see below), and may reflect the generally high nitrogen supply of the upwelling regime. The well mixed nature of the water column may also be responsible for the low vertical variability in ammonium oxidation rates; cells may not be exposed to inhibitory light intensities for long enough to inhibit their activity greatly.

Nitrification rates have been measured at other locations in California coastal waters using essentially the same tracer methods. In the Southern California Bight, ammonium oxidation showed a very strong subsurface maximum, and the maximum rates $\left(\sim 40 \mathrm{nmol} \mathrm{l^{-1 }} \mathrm{d}^{-1}\right)$ were less than the maximum rates observed in Monterey Bay. In depth profiles extending to $>800 \mathrm{~m}$, the rates in the maxima exceeded those at both shallower and deeper depths by a factor of up to 80 -fold (Ward 1987). In more extensive depth profiles, extending to $3500 \mathrm{~m}$, ammonium oxidation rate decreased rapidly with increasing depth in a manner that could be modeled as a power function (Ward \& Zafiriou 1988). In those profiles from the Eastern Tropical North Pacific, the highest ammonium oxidation rates $\left(22 \mathrm{nmol} \mathrm{l}^{-1} \mathrm{~d}^{-1}\right.$, measured at the bottom of the euphotic zone) were in the range of the lowest rates $\left(17.5 \mathrm{nmol} \mathrm{l}^{-1} \mathrm{~d}^{-1}\right)$ measured in Monterey Bay. All these earlier studies were snapshots in time, and did not address temporal variability. They did, however, include a much greater depth range. It seems likely therefore, that the appearance of fairly uniform rates observed in the current study might be due to the limited depth range investigated. Measurement of nitrification rates in a depth profile to $900 \mathrm{~m}$ at the Monterey Bay station would address this hypothesis.

Chlorophyll a concentration and $\mathrm{NH}_{4}{ }^{+}$assimilation rates were measured together on only 3 dates (December 1998, February 1999, July 1999), which limits the comparisons that can be made. Within this small data set, however, there was a strong positive relationship between the two (Fig. 10). Notably, the coincident data sets do not include the dates on which a deep subsurface maximum in chlorophyll $a$ was present; these 


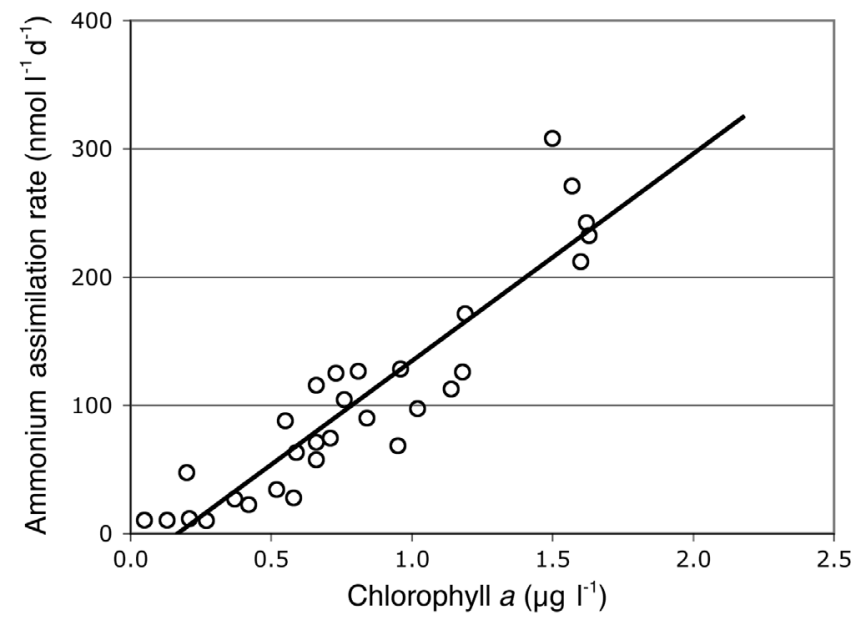

Fig. 10. Relationship between chlorophyll $a$ and ammonium assimilation rates in Monterey Bay for 3 dates (December 1998, February 1999, July 1999 combined) for which both measurements are available. Ammonium assimilation rate $=$ 161.6 [chl $\left.\mu \mathrm{g} \mathrm{l}^{-1}\right]-26.8\left(\mathrm{~N}=30 ; \mathrm{R}^{2}=-0.85\right)$

would have produced a more complex relationship between chlorophyll $a$ and ammonium assimilation rates. Given the high concentrations of nitrate observed throughout most of this study, it is likely that ammonium was not the major $\mathrm{N}$ source for the phytoplankton assemblage. Therefore, it is not clear if a relationship between ammonium assimilation rate and biomass should prevail, as we would expect large diatoms to dominate and to assimilate nitrate preferentially, at least at some times of the year. The 3 dates (combined data in Fig. 10) included times of relatively low (about 5 $\mu \mathrm{M}$ throughout the water column, February 1999) and high (over $20 \mu \mathrm{M}$, July 1999) nitrate concentrations.

Because $\left[\mathrm{NO}_{3}{ }^{-}\right]$consistently increased with increasing depth while nitrification rate often showed a maximum at intermediate depths, there was no simple relationship between the two. There was a weak inverse relationship between $\left[\mathrm{NO}_{3}{ }^{-}\right]$and temperature, as expected from the typical opposite relationships between the 2 variables and depth (Fig. 11). The effect of annual and seasonal variability superimposed on the depth variation in both distributions is illustrated clearly by the differences between February and April of 1998, and July 1999. In February 1998, $\left[\mathrm{NO}_{3}^{-}\right]$was minimal and temperature was the highest observed throughout the surface layer. In April of the same year, the situation was reversed-much cooler water and much higher $\left[\mathrm{NO}_{3}{ }^{-}\right]$places this date in the extreme upper left of the plot in Fig. 11. July 1999 was intermediate, with warmer water and lower $\left[\mathrm{NO}_{3}{ }^{-}\right]$than April 1998. A linear regression between $\left[\mathrm{NO}_{3}{ }^{-}\right]$and temperature is anchored by the 10 points from February 1998 at the lower right corner of Fig. 11 (all overlapping filled cir-

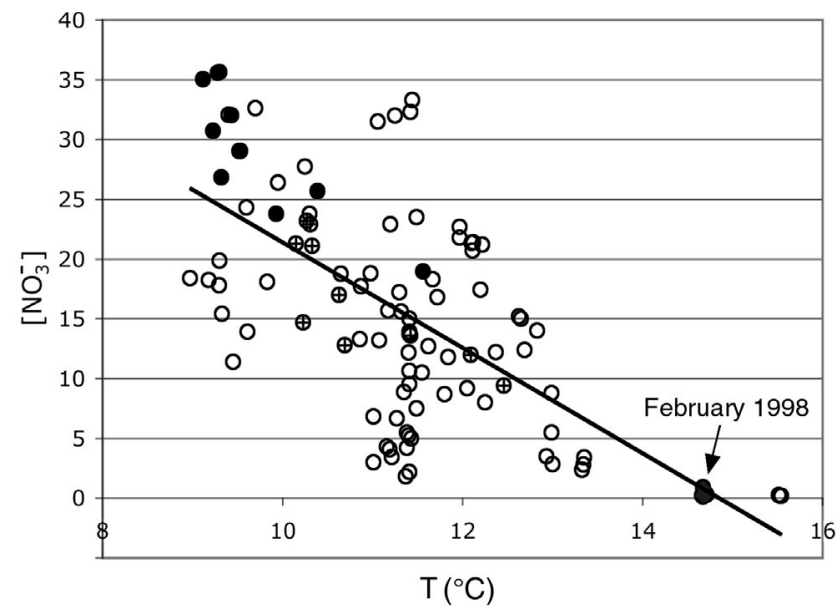

Fig. 11. Relationship between $\left[\mathrm{NO}_{3}{ }^{-}\right]$and temperature in Monterey Bay, showing all data (O), and subsets from February 1998 (arrowed), April 1998 (• and July $1999(\oplus)$. Trend line $\left(\left[\mathrm{NO}_{3}{ }^{-}\right]=-4.42 \mathrm{~T}+65.6 ; \mathrm{R}^{2}=0.51\right)$ computed on basis of complete data set $(\mathrm{N}=110)$

cles on the $x$-axis at $14.7^{\circ} \mathrm{C}$ ), and explains just over half the variability in the $\left[\mathrm{NO}_{3}{ }^{-}\right]$data.

There was no significant relationship between $\left[\mathrm{NO}_{3}{ }^{-}\right]$ and chlorophyll a abundance when all data combined were considered. Thus it is clear that sampling on this time scale does not capture the short term cause and effect between nutrient supply of primary production and phytoplankton biomass. For example, lowest surface chlorophyll a values occurred in August and October of 1998, the 2 dates for which distinct subsurface chlorophyll maxima were observed. In August 1998, $\left[\mathrm{NO}_{3}{ }^{-}\right]$was high throughout the water column, whereas in October 1998, $\left[\mathrm{NO}_{3}^{-}\right]$was relatively depleted $(<5 \mu \mathrm{M})$ above $45 \mathrm{~m}$. This suggests that the high $\left[\mathrm{NO}_{3}{ }^{-}\right]$ recorded in August may have represented the initial stage of an episodic upwelling event, when nitrate had welled up into surface waters but phytoplankton had not yet responded to the elevated nutrient levels, while in October, the chlorophyll biomass represented the drawdown of $\left[\mathrm{NO}_{3}^{-}\right]$from a previous upwelling injection. Thus, the chlorophyll $a$ and nitrate distributions imply much greater variability in the biological processes than the hydrography alone would suggest.

Total chlorophyll a concentrations were maximal at intermediate temperatures, but due to the minimal range of values in both variables, this is not a very informative relationship. On the first 6 cruises (1998), but at slightly different depths, size-fractionated chlorophyll a concentrations were measured at the same station (F. Wilkerson et al. unpubl.). Most of the chlorophyll $a$ was present in the $>5 \mu \mathrm{m}$ size fraction throughout the year, consistent with a diatom-dominated nitrate-driven system. There were, however, important 


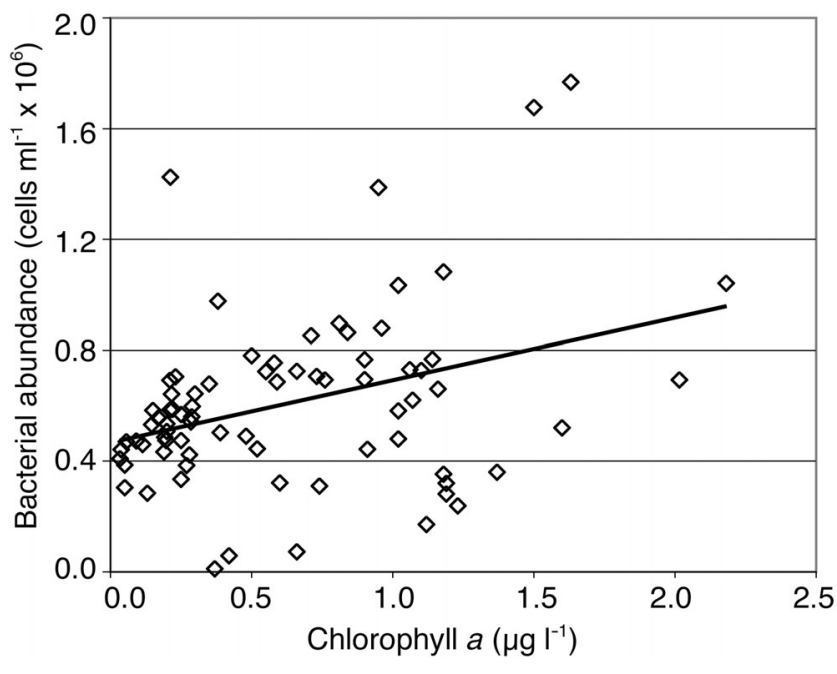

Fig. 12. Relationship between bacterial abundance and chlorophyll $a$ concentration in Monterey Bay for entire data set $\left(\mathrm{N}=110, \mathrm{R}^{2}=0.1234\right)$. Cells $\mathrm{ml}^{-1}=2.2 \times 10^{5}\left[\mathrm{chl} \mathrm{a} \mu \mathrm{g} \mathrm{l}^{-1}\right]$ $+4.7 \times 10^{5}$

exceptions. In February 1998 (the El Niño year) when $\left[\mathrm{NO}_{3}{ }^{-}\right]$was negligible in the surface layer, only $33 \%$ of the chlorophyll $a$ was in the $>5 \mu \mathrm{m}$ fraction throughout the euphotic zone. In April, when $\left[\mathrm{NO}_{3}{ }^{-}\right]$was among the highest concentrations observed in this study, 95 to $100 \%$ of the chlorophyll a was larger than $5 \mu \mathrm{m}$. In October and December, the larger size fraction dominated only in the deeper samples. The size-fractionated data are available only for depths representing $>1 \%$ of surface light intensity; the total chlorophyll $a$ data shown in Fig. 4 extend twice as deep, to the $0.1 \%$ light depth. In August and October, the deep chlorophyll a maximum occurred within the 1 to $0.1 \%$ depth interval.

Despite much scatter, there is a significant relationship $\left(\mathrm{R}^{2}=0.123 ; \mathrm{p}=0.002\right)$ between chlorophyll a concentration and bacterial abundance over the data set as a whole (Fig. 12). In addition, the highest integrated chlorophyll value coincided with the highest integrated bacterial abundance (July 1999). This correlation is often observed (Fuhrman \& Azam 1980, Ducklow 1984), implying the fundamental, if not always direct, dependence of the bacterioplankton on primary production and the photosynthetic biomass.

The biological variables were integrated over the depth interval sampled, using trapezoidal integration. None showed strong correlations with any other (data not shown). There was a weak negative relationship between integrated chlorophyll $a$ and $\left[\mathrm{NO}_{3}{ }^{-}\right]$, but the analysis was weakened by the small number of data points. The lack of correlation is clear in the plot of integrated variables versus time throughout the duration of the study (Fig. 13). All 4 variables varied by a factor of 2 or more over the $2 \mathrm{yr}$ period, but neither covaried with each other nor exhibited repeated annual patterns. Two years, especially when one is an El Niño year, are not long enough to detect robust annual patterns, but the complete lack of such here implies that the sampling schedule was not sufficient to detect potential relationships that depend on variable time lags. While upwelling is a dominant feature of this environment, it is clear that ammonium oxidation rates were not correlated with upwelling in a simple manner. The $10 \mathrm{yr}$ averaged upwelling index for Monterey Bay, computed from the local sea-surface pressure fields (NOAA), shows maximum upwelling in June, followed by July, August and May, and downwelling in December and January. The patterns at the monthly scale for 1998 (data for 1999 not available) did not vary significantly from the long-term average, and there was no relationship between upwelling index and ammonium oxidation rate.

\section{Relationship between ammonium oxidation rates and diversity of ammonia-oxidizing bacteria}

This study examined the direct interaction of environmental variation and nitrification rates, but no pat-

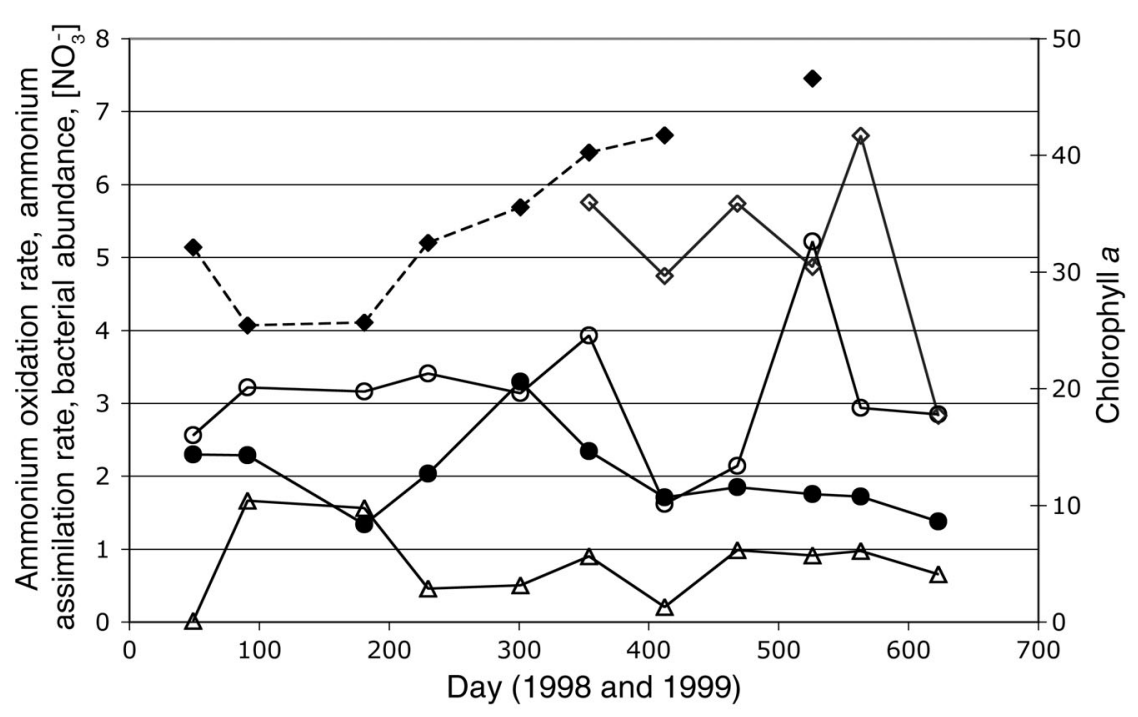

Fig. 13. Time course of integrated values over the 2 yr sampling period in Monterey Bay. Ammonium oxidation rate $\left(\bullet, \mu \mathrm{mol} \mathrm{m} \mathrm{m}^{-2} \mathrm{~d}^{-1}\right)$; ammonium assimilation rates $\left(\diamond, \mu \mathrm{mol} \mathrm{m} \mathrm{m}^{-2} \mathrm{~d}^{-1}\right)$; bacterial abundance $\left(\mathrm{O}\right.$, cells $\left.\mathrm{m}^{-2} \times 10^{9}\right)$; $\left[\mathrm{NO}_{3}{ }^{-}\right]$ $\left(\Delta, \mathrm{mmol} \mathrm{m}^{-2}\right)$; chlorophyll $a\left(\diamond, \mu \mathrm{g} \mathrm{m}^{-2}\right)$ 
terns emerged on the time scale of the sampling program. This suggests that ammonia-oxidizing bacterial (AOB) population dynamics in response to environmental variation may control nitrification rates. The second impetus for the design of this study was to investigate the relative scales of temporal and spatial variability between the Monterey Bay ecosystem and that of the adjacent Elkhorn Slough, an estuary that empties into the bay at approximately its geographic center. Elkhorn Slough is a shallow tidal embayment that contributes a small freshwater input to the bay on a highly seasonal basis. Its ecology and biogeochemistry have been well described elsewhere (Caffrey 2003). In companion studies carried out over roughly the same time period as the Monterey Bay study reported here (Caffrey et al. 2002, 2003), potential nitrification rates (measured in sediment slurries) and supporting measurements were made at monthly or slightly longer intervals at 5 sites in the slough. Although the slough sites varied amongst themselves in terms of their temporal variability, they all showed strong seasonal trends in temperature (Caffrey et al. 2002) and increasing salinity (from nearly fresh in the spring up to 40 or 70 , depending on site) in latesummer. Nitrification rates varied among sites and over time; maximum potential nitrification rates varied by up to 500 -fold within a single site during the course of a year (Caffrey et al. 2003). This represents a dramatically greater seasonal variation than observed in the adjacent bay, where integrated rates varied by no more than 2.5-fold over 2 yr.

The comparison of absolute rates and the variability in rates and physical parameters between Monterey Bay and Elkhorn Slough is complicated by the fact that biogeochemical transformations in the water column are dominant in one system and in shallow sediments in the other. This difference may be reflected in the composition of microbial communities as well as the sensitivity of the system to environmental forcing. In addition, the nitrification rates cited for Elkhorn Slough were 'potential' rates, measured in sediment slurries with added ammonium and enhanced oxygen availability through shaking (Caffrey et al. 2002). The variability in Elkhorn Slough may therefore reflect variability in the microbial community and differences in community composition as much as it indicates the magnitude of in situ rates and their response to environmental variables. Although our data do not directly quantify the rate of environmental change in the 2 environments, it is clear that the range of environmental conditions is much greater and varies on much smaller time scales in the slough versus the bay. The time scale of environmental variability in the bay may allow the AOB community to respond by changing its composition to optimize its activity. Changes in the composition of the AOB community could effectively smooth-out overall observable rate processes in the bay, whereas the more rapid and dynamic environmental variability in the slough elicits a more direct response of the AOB community, which although changing to meet new conditions, is often not able to respond rapidly enough to optimize its activity. It would be necessary to evaluate the composition of the AOB community over the time-scales of the rate investigation in order to test this hypothesis.

The diversity of AOB was investigated in both the bay and slough samples (Caffrey et al. 2003, O'Mullan $\&$ Ward 2005). AOB 16S rDNA sequences were obtained from 3 sites in the Slough in August 1999, and partial ammonia monooxygenase A (amoA) gene sequences were obtained from 1 site (Azevedo Pond) in August 1999. All the clone libraries were dominated by 16S rRNA or amoA gene sequences that were similar to sequences from cultivated Nitrosomonas marina; 2 different sets of $16 \mathrm{~S}$ rRNA primers, both specific for beta-subdivision ammonia-oxidizers, yielded the same phylogenetic associations, which suggests that the dominance of $N$. marina-like sequences in the Slough is not a methodological artifact. In contrast, 16S rRNA clone libraries in the bay (analyzed for April and October in 1998 and 1999 at 1 to 3 depths per station) were dominated by Nitrosospira-like sequences; Nitrosomonas-like sequences were detected only in October 1999. amoA sequences from the same Monterey Bay samples were also dominated by Nitrosospira-like sequences, but exhibited greater diversity and most clones were not closely related to any sequences from cultivated ammonia oxidizers. Nitrosospira-like 16S rRNA sequences dominated $\beta$-AOB clone libraries from the Arctic ocean (Bano \& Hollibaugh 2000). In the Mediterranean, Nitrosospira-like 16S rRNA sequences were most important in clone libraries derived from planktonic samples, while sequences related to $N$. eutropha dominated clones derived from particulate material (Phillips et al. 1999). These results, along with the Monterey Bay/Elkhorn Slough comparison, are all consistent with the idea that Nitrosospira strains are adapted to lower substrate levels and Nitrosomonas strains are more prevalent in high nutrient environments.

The Monterey Bay amoA sequences exhibited greater variability than did the $16 \mathrm{~S}$ rRNA sequences, sometimes exhibiting greater diversity differences between samples collected $30 \mathrm{~m}$ apart at the same time than between April and October samples at the same depth. The patterns of community composition derived from amoA and 16S rRNA sequences for ammoniaoxidizers in the bay did not correlate significantly with the observed nitrification rates (O'Mullan \& Ward 2005), probably because there was so little variability 
in the measured rates. The diversity in the bay is perhaps surprising, given the relatively stable physical characteristics of the environment. The extent to which sequence diversity in functional genes influences enzyme function is an intriguing question in microbial ecology. The observed AOB diversity in Monterey Bay, at both the 16S rRNA and amoA sequence level may imply that the biological interactions, in terms of nutrient cycling, the activity of different phytoplankton, and activity of different heterotrophic planktonic groups, are more important in determining the composition of the assemblage than direct physical factors of the environment. Direct chemical and physical forcing of nitrification rates was not evident on the time scales resolved here. However, biological processes appear to be more dynamic than seasonal hydrographic variability would predict, emphasizing the dynamic nature of biological processes.

Acknowledgements. I thank the various members of my laboratory who participated in the field work and assisted with a variety of analyses over the course of the project. J. Caffrey made some of the nutrient measurements and did all the chlorophyll a analyses. M. E. Hogan and J. Granger counted some of the DAPI samples. N. Harrington ran some of the nutrient measurements. D. Martino, B. Carter, N. Harrington, I. Solem, J. Caffrey and J. Granger all assisted in field work. D. Schmitt made the mass-spectrometry measurements.

\section{LITERATURE CITED}

Bano N, Hollibaugh JT (2000) Diversity and distribution of DNA sequences with affinity to ammonia-oxidizing bacteria of the beta subdivision of the class Proteobacteria in the Arctic Ocean. Appl Environ Microbiol 66:1960-1969

Bruland KW, Rue EL, Smith GJ (2001) The influence of iron and macronutrients in coastal upwelling regimes off central California: implications for extensive blooms of large diatoms. Limnol Oceanogr 46:1661-1674

Caffrey JM (2003) Changes in a California Estuary: A profile of Elkhorn Slough. Elkhorn Slough Foundation, Monterey, CA

Caffrey JM, Harrington NE, Ward BB (2002) Biogeochemical processes in a small California estuary: 1. Benthic fluxes and pore water constituents reflect high nutrient freshwater inputs. Mar Ecol Prog Ser 233:39-52

Caffrey JM, Harrington NE, Solem IP, Ward BB (2003) Biogeochemical processes in a small California estuary, Elkhorn Slough, CA. 2. Nitrification activity, community structure and role in nitrogen budgets. Mar Ecol Prog Ser 248:27-40

Carlucci AF, Strickland JDH (1968) The isolation, purification and some kinetic studies of marine nitrifying bacteria. J Exp Mar Biol Ecol 2:156-166

Ducklow HW (1984) Geographical ecology of marine bacteria: Physical and biological variability at the mesoscale. In:

Editorial responsibility: Victor de Jonge (Contributing Editor), Haren, The Netherlands
Klug MJ, Reddy CA (eds) Current perspectives in microbial ecology. American Society for Microbiology, Washington, DC, p 22-30

Dugdale RC, Goering JJ (1967) Uptake of new and regenerated forms of nitrogen in marine production. Limnol Oceanogr 12:196-206

Dugdale RC, Wilkerson FP, Morel A (1990) Realization of new production in coastal upwelling areas - a means to compare relative performance. Limnol Oceanogr 35:822-829

Fuhrman JA, Azam F (1980) Bacterioplankton secondary production estimates for coastal waters of British Columbia, Antarctica, and California. Appl Environ Microbiol 39: 1085-1095

Grasshof K, Ehrhardt M, Kremling K (1983) Methods of seawater analysis. Verlag Chemie, Weinheim

Hashimoto LK, Kaplan WA, Wofsy SC, McElroy MB (1983) Transformations of fixed nitrogen in the Cariaco Trench. Deep-Sea Res 30:575-590

Jones R, Morita RY (1983) Methane oxidation by Nitrosococcus oceanus and Nitrosomonas europaea. Appl Environ Microbiol 45:401-410

Kudela RM, Dugdale RC (2000) Nutrient regulation of phytoplankton productivity in Monterey Bay, California. Deep-Sea Res 47:1023-1053

O'Mullan GD, Ward BB (in press) Comparison of temporal and spatial variability of ammonia-oxidizing bacteria to nitrification rates in Monterey Bay, California. Appl Environ Microbiol 71:697-705

Olson RJ (1981a) ${ }^{15} \mathrm{~N}$ tracer studies of the primary nitrite maximum. J Mar Res 39:203-226

Olson RJ (1981b) Differential photoinhibition of marine nitrifying bacteria: a possible mechanism for the formation of the primary nitrite maximum. J Mar Res 39:227-238

Parsons TR, Maita Y, Lalli CM (1984) A manual of chemical and biological methods for seawater analysis. Pergamon Press, Oxford

Phillips CG, Smith Z, Embley TM, Prosser JI (1999) Phylogenetic differences between particle-associated and planktonic ammonia-oxidizing bacteria of the beta subdivision of the class Proteobacteria in the northwestern Mediterranean Sea. Appl Environ Microbiol 65:779-786

Strickland JDH, Parsons TR (1972) A practical handbook of seawater analysis. Bull Fish Res Board Can 67:1-310

Ward BB (1987) Nitrogen transformations in the Southern California Bight. Deep-Sea Res. 34:785-805

Ward BB (1990) Kinetics of ammonia oxidation by a marine nitrifying bacterium: methane as a substrate analogue. Microb Ecol 19:211-225

Ward BB (2002) Nitrification in aquatic systems. In: Capone DG (ed) Encyclopedia of environmental microbiology. John Wiley \& Sons, New York, p 2144-2167

Ward BB, Kilpatrick K (1990) Relationship between substrate concentration and oxidation of ammonium and methane in a stratified water column. Cont Shelf Res 10: 1193-1208

Ward BB, Zafiriou OC (1988) Nitrification and nitric oxide in the oxygen minimum of the eastern tropical North Pacific. Deep-Sea Res 35:1127-1142

Wetz MS, Wheeler PA (2003) Production and partitioning of organic matter during simulated phytoplankton blooms. Limnol Oceanogr 48:1808-1817

Submitted: May 20, 2004; Accepted: December 9, 2004

Proofs received from author(s): April 22, 2005 